\title{
AFLATOXICOSIS OF CRUCIANS: EXPERIMENTAL TREATMENT AND BIOLOGICAL VALUE OF FISH
}

\author{
Roman Petrov ${ }^{1}$ \\ romanpetrov1978@gmail.com \\ Oleksiy Pidlubniy \\ o.pidlubniy@gmail.com \\ ${ }^{1}$ Department of virusology, patanatomy and bird diseases \\ Sumy National Agrarian University \\ 160 Herasym Kondratiev str., Sumy, Ukraine, 40021
}

\begin{abstract}
The aim of this study was to investigate a possibility to decrease a toxic influence of aflatoxin on the fish organism and veterinary-sanitary evaluation of fish, fed by a pure fodder, aflatoxin and ketoconazole+aflatoxin.

Fish aflatoxicoses cause essential losses at fish growing using industrial production technologies. It is characterized by decreasing weight gains and increasing kill of commodity fish, worsening fodder conversion. Farmers often use fodders of own production, without conducting laboratory studies, and don't know about aflatoxins. At the same time because of different reasons, first of all economic ones, they don't use adsorbents for decreasing the negative influence of aflatoxins on the fish organism. Their use doesn't guarantee $100 \%$ fish resistance to micotoxicoses and correspondingly product safety for a consumer. Fish, received aflatoxins with food, is dangerous as a food product for humans and animals. Aflatoxins are very stable in the environment, so even thermal processing doesn't exceed risk of aflatoxin contamination.

The article presents a possibility of effective treatment of fish at aflatoxicosis. It is known, that aflatoxin beyond cells is not dangerous. Its activation takes place within a cell by the enzyme system cytochrome P-450, forming an epoxide, in which result the aflatoxin inclusion complex with DNA forms in the kernel. The veterinary preparation "Ketoconazole" inhibits cytochrome enzymes P-450, so aflatoxin activation within a cell doesn't take place, epoxides don't form, DNA cells are not injured, aflatoxicosis doesn't develop in fish that has been proved experimentally. The veterinary-sanitary mark of fish, treated for aflatoxicosis, is satisfactory.

The importance of this study is in fact that for today there is no developed effective method of fish aflatoxicosis treatment. An influence of aflatoxin on the crucian organism has not been studied experimentally.
\end{abstract}

Keywords: fish aflatoxicosis, micotoxins, toxic fodder, aflatoxins, cytochrome P-450, enzyme inhibitor.

DOI: $10.21303 / 2504-5695.2021 .001754$

\section{Introduction}

According to FAO, $25 \%$ of grains in the world are contaminated by micotoxins [1]. A loss, caused by microscopic fungi in the world, is estimated as 16 bil dollars annually [2].

Fodder contamination with microscopic fungi and micotoxins is often registered in Ukraine [3]. Microbiological studies have established that $21.5 \%$ of fodders in Ukraine are contaminated by fungi of Aspergillus genus [4]. Aflatoxins are related to most dangerous poisons; penetrating the fish organism, they can provoke genetic disorders, resulting in cancer and death in $100 \%$ of cases $[5,6]$. Researchers described a case of carp aflatoxicosis, caused by fish feeding with a low-quality fodder of low toxicity [7]. Fish, consuming a fodder, containing aflatoxins, is potentially dangerous, because aflatoxin and its metabolites can be contained in fish liver and other organs. Aflatoxins are stable in the environment [8].

Aflatoxins are not dangerous beyond the organism. Its activation takes place in a cell by cytochrome enzymes P-450. The formed epoxide is chemically active; penetrating a cell kernel, it forms state chemical compounds - inclusion complexes of aflatoxins and DNA. As a result of cell kernel injury, there appear mutations that are triggers of oncological diseases [9]. Among all cells of the organism, liver ones are injured mostly, because hepatomas are typical for aflatoxicosis [10]. Clinical sings at the severe clinical course of aflatoxicosis are not expressed and include refusal of 
food and unexpected death. At the chronic form, there are observed anemia, liver injuries, edema, body surface injuries, jaundice, blood coagulation disorders $[8,9]$.

Adsorbents based on aluminum silicates are used for preventing aflatoxicosis [11].

For treating fish for aflatoxicosis, a series of chemical substances was verified, but the results were ambiguous. Oxytetracycline D $(10 \mathrm{mg} / \mathrm{kg})$ at everyday intake with fodder decreases liver injuries and mortality. It is not recommended to use it with steroids. Activated carbon manifested its efficiency, especially used soon after the aflatoxin effect. According to the scientists, the combination of oxytetracycline and activated carbon is promising [9].

The aim of the work was to establish an influence of aflatoxin on the fish organism, to develop a possibility of prophylaxis and treatment of fish at aflatoxicosis.

\section{Materials and Methods}

The studies were conducted in the period from 10.11.2020 to 10.02.2021 at the department of veterinary expertise, microbiology, zoo hygiene and safety and quality of animal husbandry products of the Sumy national agrarian university and in the Sumy regional state laboratory of the State food consumption service (Ukraine). All studies were conducted in correspondence with ARRIVE recommendations and EU Guideline 2010/63.

For conducting the experiment, three groups of crucians were formed by the analogue principle: two experimental and one control of thirty individuals in each one (weight $40 \pm 16 \mathrm{~g}$ ), grown at the LLC «Sumyribgosp», Ukraine, successful for main infectious diseases and micotoxicoses. All groups of fish were female. Fishes of control and experimental groups were placed in separate aquariums of $100 \mathrm{l}$. At temperature $18-20^{\circ} \mathrm{C}$, the oxygen concentration at level $7-10 \mathrm{~g} / \mathrm{m}^{3}$ was kept in water by artificial aeration. The acclimatization period in both groups was 21 days. A mixed fodder "Tetra sticks" was used for feeding all groups.

An individual diet was used for each group:

1. The mixed fodder with added aflatoxin in dose $0.4 \mathrm{mg} / \mathrm{kg}$ was used for the first group.

2. The mixed fodder, added with aflatoxin in dose $0.4 \mathrm{mg} / \mathrm{kg}$ and ketaconazole in dose $1 \mathrm{~g} /$ $\mathrm{kg}$ was used for the second group.

3. The pure mixed fodder was used for the third group.

For adding aflatoxin in the mixed fodder, $96 \%$ ethyl alcohol solution, added with $1 \mathrm{ml}$ of aflatoxin $(10 \mathrm{mg} / \mathrm{ml})$, was used. The mixed fodder was processed by aerosol, by the spraying method.

For preparing the solution "Ketoconazole”, produced by «MX and Gustav GEEC, Ukraine» LTD, batch number KNT/1910068, production date 10/2019, $96 \%$ ethyl alcohol solution, added with 99,3\% "Ketoconazole", was used. This solution was heated to boiling, after that few crystals of $99.5 \%$ lemon acid were added to complete dissolution of ketoconazole. The fodder with aflatoxin was processed by this solution by the aerosol spraying method.

Ichthyopathologic studies, ones of fish quality and safety were conducted at the department of veterinary expertise, microbiology, zoo hygiene and safety and quality of animal husbandry products of the Sumy national agrarian university by conventional methods $[2,12,13]$.

Peripheral blood was taken from the caudal artery by cutting off the caudal peduncle near the pelvic fin. The blood was stabilized, adding $10 \%$ EDTA, 1 drop for $1 \mathrm{ml}$ of blood.

Hematological studies were conducted according to the conventional methods. The number of erythrocytes and leucocytes was calculated in the Goyaev's chamber, hemoglobin concentration by Sahli using a hemometer. 2 smears were made for each individual. The leukocytic formula was derived by the results of differentiated calculation of 200 cells in smears, stained by Puppenheim under a microscope, using the immersion system [3].

The relative biological value was determined according to "Methodical recommendations for determining safety and biological value of fish using infusorians Tetrahymena pyriformis» (2009). The method is based on determination of the intensity of infusorians multiplication on a nutritive substrate, containing the studied samples as a source of protein and growth stimulators.

The obtained results were processed biometrically, using the program software Microsoft Excel 2007 


\section{Results}

Group No. 1 on 5-7 day demonstrated clinical signs of aflatoxicosis, characterized with decelerated swimming movements, fish became to react weakly to stimuli, appetite worsened. Hemorrhages were observed on the body (Fig. 1), tail exfoliation (Fig. 2).

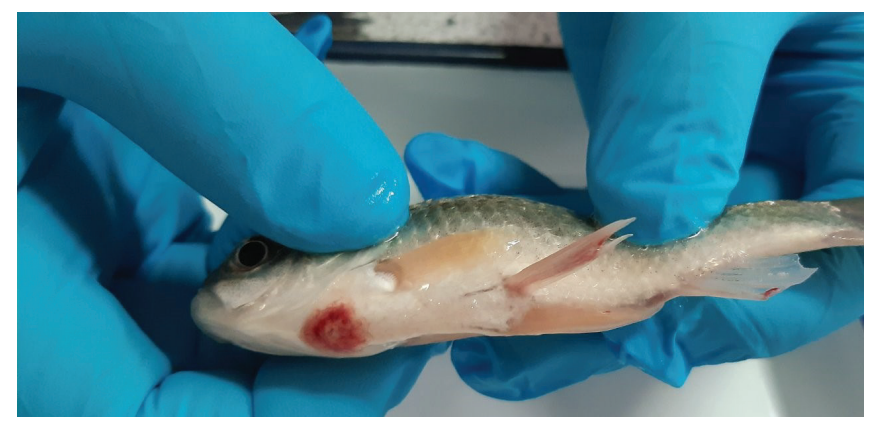

Fig. 1. Hemorrhages in the low part of the head (5 day of the experiment)

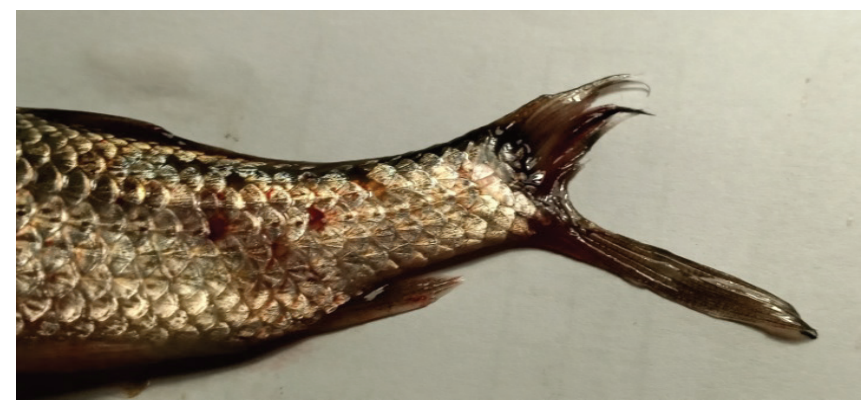

Fig. 2. Tail exfoliation (7 day of experiment)

On 21 day, two individuals died, changes were observed in their liver (Fig. 3), comparing with the norm (Fig. 4).

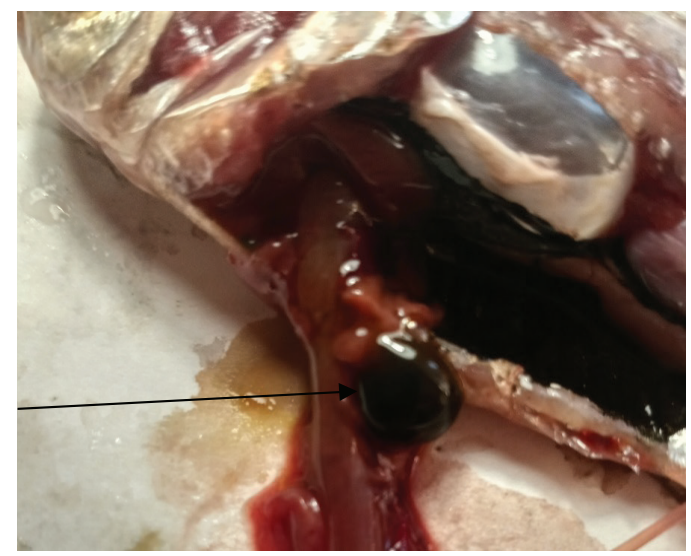

Fig. 3. Liver increase on 21 day of the experiment

On 28 day 17 individuals died. Liver structure disorders were observed at autopsy, the gallbladder content was yellow (Fig. 5). It was impossible to identify kidneys in $50 \%$ of individuals.

The content of the abdominal cavity was changed, and only the intestine was distinctly identified (Fig. 6). 


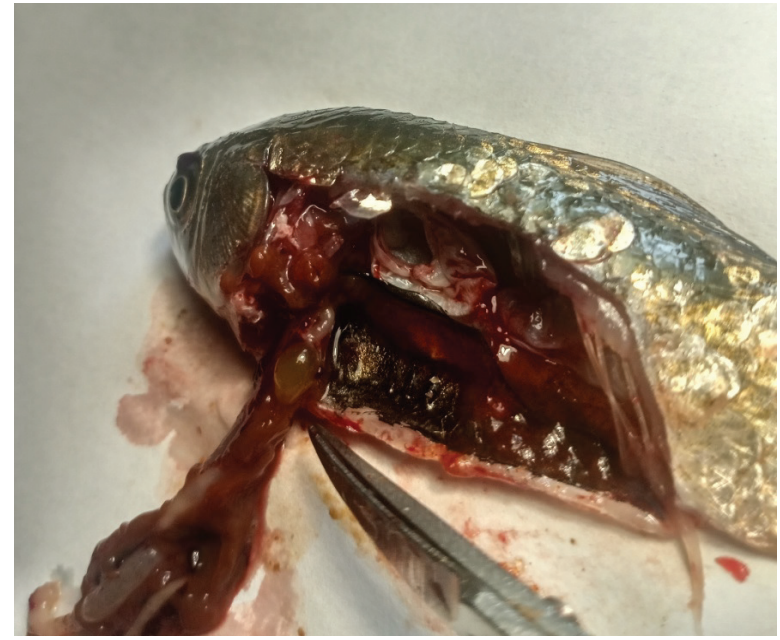

Fig. 4. Liver and gallbladder of the control group (norm)

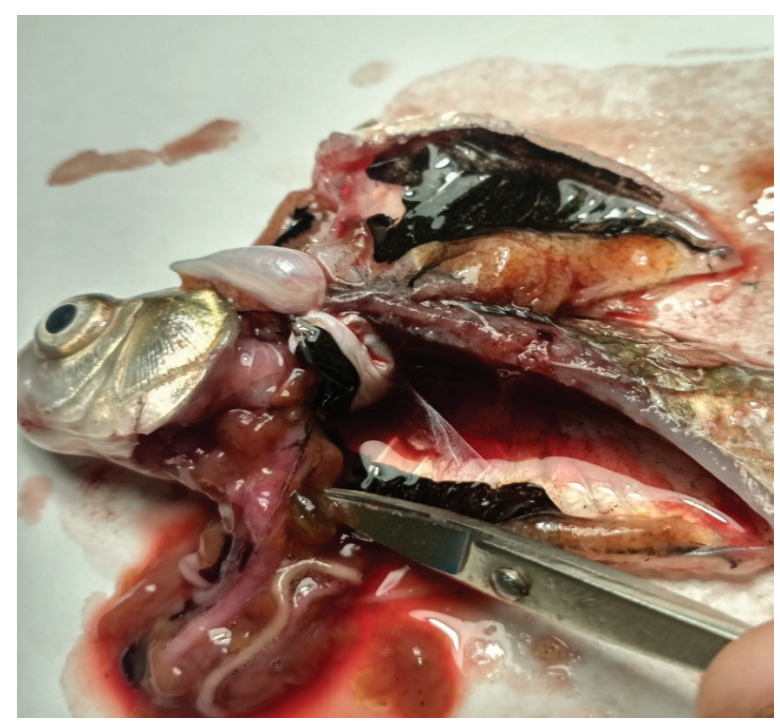

Fig. 5. Change of the gallbladder color, liver is light, flabby, its structure is weakly expressed. 28 day of the experiment

On 37 day of the experiment 5 fish individuals died and on 39 day of the experiment all fishes died, at that LD 50 is $0.44 \mathrm{mg} / \mathrm{kg}$ of fodder.

In group No. 2, received the fodder with aflatoxin and "Ketoconazole", fish death was not observed. Clinical signs of aflatoxicosis were not fixed.

In group No. 3, control, received the pure fodder, fish death was not observed. Clinical signs of aflatoxicosis were not fixed. Fish had also good appetite and a positive dynamics of weight gain was observed.

As it was testified by hematological studies, aflatoxin positively influences the blood picture of crucians. The data of hematological studies are presented in Table $\mathbf{1 .}$

Table 1 demonstrates that in fishes from experimental group 1 that were not treated, the hemoglobin concentration decreased by $38.65 \%$, the number of erythrocytes also decreased by $33.89 \%$, comparing with the control. The total number of leucocytes increased by $21.69 \%$, and the increase of segment-kernel neutrophils is observed against this background. Changes of blood parameters in experimental group 2, received "Ketoconazole" preparation together with aflatoxin, were not reliable, comparing with the control group. 


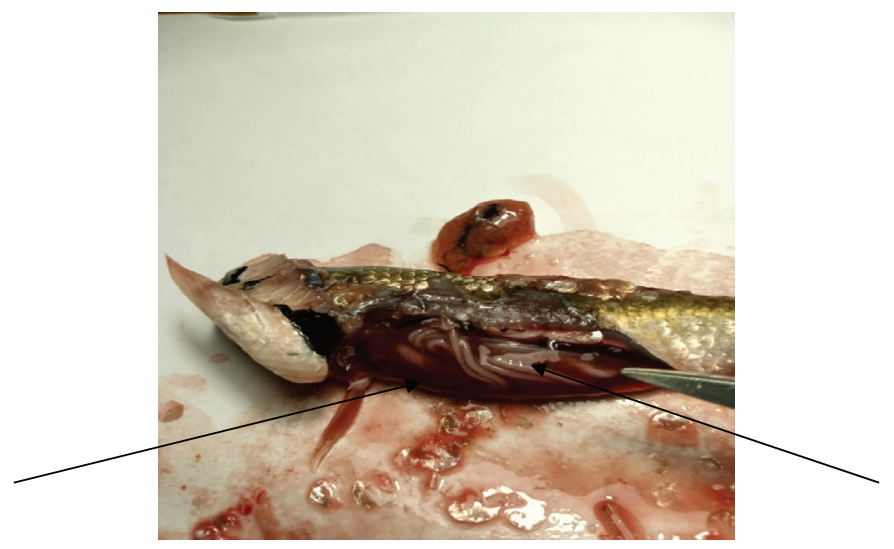

Fig. 6. Change in the abdominal cavity, filled with the jelly-like brown mass (indicated by the arrow on the left), where only intestine loops are identified (indicated by the arrow on the right);

37 day of the experiment

Table 1

Hematological indices of crucian blood on 30 day, $M \pm m(n=30)$

\begin{tabular}{ccccc}
\hline No. item & Parameters & $\begin{array}{c}\text { Experimental group 1 } \\
\text { (aflatoxin) }\end{array}$ & $\begin{array}{c}\text { Experimental group 2 } \\
\text { (aflatoxin+“Ketoconazole") }\end{array}$ & Control group \\
\hline 1 & Hemoglobin, g/1 & $37.48 \pm 1.35^{* * *}$ & $60.55 \pm 2.78$ & $61.1 \pm 0.59$ \\
2 & Number of erythrocytes, mln/mcl & $0.78 \pm 0.03$ & $1.24 \pm 0.18$ & $1.18 \pm 0.18$ \\
3 & Number of leucocytes, thousand/ & $41.79 \pm 0.31^{* * *}$ & $32.44 \pm 2.10$ & $34.34 \pm 0.29$ \\
& mcl & - & - & - \\
5 & Stab neutrophils, \% & $2.13 \pm 0.19^{* * *}$ & $0.70 \pm 0.11$ & $0.79 \pm 0.07$ \\
6 & Segment-kernel neutrophils, \% & $3.58 \pm 1.05$ & - & - \\
7 & Eosinophils, \% & $4.55 \pm 0.56^{* * *}$ & $0.50 \pm 0.07$ & $0.63 \pm 0.07$ \\
8 & Basophils, \% & $4.01 \pm 0.58^{* * *}$ & $0.93 \pm 0.74$ & $1.63 \pm 0.13$ \\
9 & Monocytes, \% & $83.63 \pm 2.18^{* * *}$ & $98.13 \pm 1.48$ & $96.95 \pm 1.31$ \\
10 & Lymphocytes, \% & $2.19 \pm 0.97$ & - & $0.76 \pm 0.05$
\end{tabular}

Note $* * *-P<0.001$.

The number of changed erythrocytes in the total number of red blood cells in separate individuals (experimental group 1) varied from $10 \%$ to $41 \%$. It is possible to separate the following disorders by character and manifestation degree: staining change (hypochromasia); vacuolization of the kernel and cytoplasm - high presence of kernel tissues. From $12 \%$ to $25 \%$ of all erythrocytes were hypochromized cells. At that cytoplasm parts, poor in hemoglobin, occupied the essential surface of erythrocyte, and only a little zone kept a possibility to be stained (Fig. 7).

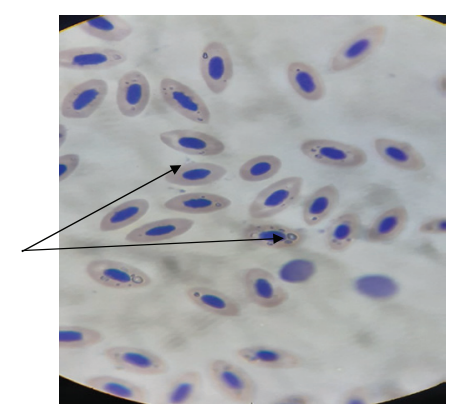

Fig. 7. Hypochromasia of erythrocytes, staining by Pappenheim $\times 900$ 
Intracellular metabolism disorders were testified by vacuolization of both cytoplasm and kernel. Cytoplasm vacuolization (Fig. 8) was observed in $62.1 \%$ of crucians, at that the intensity of its manifestation in separate individuals was high and reached $30.0 \%$. Despite the fact that kernel vacuolization was observed in the little number of fishes $(4.5 \%)$, its presence testifies to the pathological process severity.

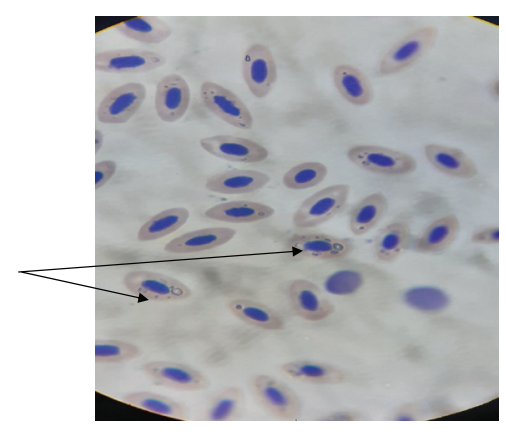

Fig. 8. Erythrocyte cytoplasm vacuolization, staining by Pappenheim $\times 900$

Degenerative changes of erythrocytes (kernel shades), formed after complete disintegration of cytoplasm, were present in most smears of the experimental group (Fig. 9).

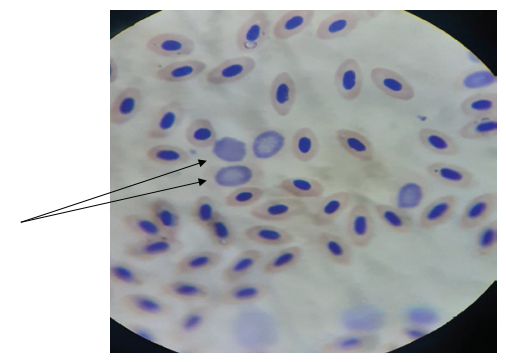

Fig. 9. Kernel shades, staining by Pappenheim $\times 900$

Thus, the results of the conducted hematological study testify to deep and in several cases irreversible changes, taking place in the fish organism under the effect of aflatoxin.

Pathological changes of blood were not observed in groups No. 2 and No. 3.

The biological value of crucian of the different groups, taken part in the experiment, has been studied. The results are presented in Table 2.

Table 2

Biological value of crucian $(M \pm m, n=20)$

\begin{tabular}{ccc}
\hline Crucian group & $\begin{array}{c}\text { Number of infusorians, } \\
\times \mathbf{1 0}_{\mathbf{6}} / \mathbf{c m}^{\mathbf{3}} \mathbf{o f} \text { the medium }\end{array}$ & $\begin{array}{c}\text { Relative biological val- } \\
\mathbf{u e} \mathbf{\%} \text { of the control }\end{array}$ \\
\hline Experimental group 1 (aflatoxin) & $43.3 \pm 2.3^{* * *}$ & 57.5 \\
Experimental group 2 (aflatoxin+Ketoconazole) & $71.0 \pm 2.7$ & 94.3 \\
Control group (healthy fish) & $75.3 \pm 2.5$ & 100 \\
Control (glucose) & $75.6 \pm 1.7$ & 100
\end{tabular}

Note: $* * * P<0.01$.

Table 2 testifies that the biological value of fish, treated by ketoconazole, doesn't reliably differ from the control group that testifies to the effectiveness and consumption safety of the proposed treatment. 


\section{Conclusions}

Aflatoxin in dose $0.4 \mathrm{mg} / \mathrm{kg}$ results in $100 \%$ death of crucians during 39 days. LD 50 of aflatoxin for crucians is $0.44 \mathrm{mg} / \mathrm{kg}$ of fodder.

Introduction of aflatoxin in the crucians' fodder in dose $0.4 \mathrm{mg} / \mathrm{kg}$ and "Ketaconazole" in dose $1 \mathrm{~g}$ for $1 \mathrm{~kg}$ of fodder improves fish preservation.

The biological value of crucian, treated by "Ketoconazole" is $94 \%$, comparing with the control.

Fish, received aflatoxin and treated by ketoconazole, can be used without limitations after the safety interval.

\section{References}

[1] Mycotoxins: economic and Health Risks. Task force Reports No. 116. CAST, 21-43. Available at: https://www.cast-science.org/ wp-content/uploads/2002/11/CAST_R116_Mycotoxins-Economic-and-Health-Risks-NOV-1989.pdf

[2] Boutrif, E., Canet, C. (1998). Mycotoxin prevention and control: FAO programmes. Revue de Médecine Vétérinaire, 149, 681-694.

[3] Davydov, O. N., Temnihanov, Yu. D., Kurovskaya, L. Ya. (2005). Patologiya krovi ryb. Kyiv: Inkos, 212.

[4] Vasianovych, O. M. (2007). Biotekhnolohiya T-2 toksynu ta obgruntuvannia maksymalno dopustymoho rivnia yoho v kormakh dlia molodniaku velykoi rohatoi khudoby na vidhodivli. Bila Tserkva, 20.

[5] Coulombe, R. A. (1993). Biological Action of Mycotoxins. Journal of Dairy Science, 76 (3), 880-891. doi: https://doi.org/ 10.3168/jds.s0022-0302(93)77414-7

[6] Frisvad, J. C., Thrane, U., Samson, R. A., Pitt, J. I. (2006). Important mycotoxins and the fungi which produce them. Advances in Food Mycology, 3-31. doi: https://doi.org/10.1007/0-387-28391-9_1

[7] Vovk, N. I., Bozhyk, V. Y. (2014). Ikhtiopatolohiya. Kyiv: Ahroosvita, 250.

[8] Abdelhamid, A. M. (2007). Mycotoxicoses In Fish With Special Emphasis On The Egyptian Situation. Available at: https:// en.engormix.com/mycotoxins/articles/mycotoxicoses-in-fish-t33692.htm

[9] Santacroce, M. P., Conversano, M. C., Casalino, E., Lai, O., Zizzadoro, C., Centoducati, G., Crescenzo, G. (2007). Aflatoxins in aquatic species: metabolism, toxicity and perspectives. Reviews in Fish Biology and Fisheries, 18 (1), 99-130. doi: https:// doi.org/10.1007/s11160-007-9064-8

[10] Rucker, R. R., Yasutake, W. T., Wolf, H. (1961). Trout Hepatoma - A Preliminary Report. The Progressive Fish-Culturist, 23 (1), 3-7. doi: https://doi.org/10.1577/1548-8659(1961)23[3:thapr]2.0.co;2

[11] Semenenko, M. P., Antipov, V. A., Kuzminova, E. V., Troshin, A. N., Tyapkina, E. V., Fersunin, A. V. (2014). The use of natural bentonite in animal husbandry and veterinary medicine. Krasnodar, 51. Available at: https://www.elibrary.ru/ item.asp?id=22788964

[12] Yatsenko, I. V., Bohatko, N. M., Bulhakova, N. V. et. al. (2017). Hihiena i ekspertyza kharchovykh hidrobiontiv ta produktiv yikh pererobky. Chastyna 1. Hihiena i ekspertyza rybopromyslovoi produktsiyi. Kharkiv: Dysa Plius, 680.

[13] Vlizlo, V. V., Fedoruk, R. S., Ratych, I. B. et. al. (2012). Laboratorni metody doslidzhen u biolohiyi, tvarynnytstvi ta veterynarniy medytsyni. Lviv, 764.

Received date 16.02.2021

Accepted date 18.03.2021

Published date 31.03.2021
(C) The Author(s) 2021

This is an open access article under the CC BY license (http://creativecommons.org/licenses/by/4.0).

How to cite: Petrov, R., Pidlubniy, O. (2021). Aflatoxicosis of crucians: experimental treatment and biological value of fish. EUREKA: Life Sciences, 2, 25-31. doi: https://doi.org/10.21303/2504-5695.2021.001754 